\title{
Occurrences of sulphide minerals in the Stak and Tso Morari eclogites: Implications for the behaviour of sulphur and chalcophile elements in subduction zones.
}

\author{
Nicolas Riel ${ }^{1}$, Keiko Hattori ${ }^{2 *}$, Stephane Guillot ${ }^{1}$, Mohamad Latif ${ }^{3}$ and Allah B Kausar ${ }^{3}$ \\ 1 University of Grenoble, OSUG - CNRS, BP 53, 38041 Grenoble Cedex 9, FRANCE \\ 2 Department of Earth Sciences, University of Ottawa, Ottawa, Ontario, K1N 6N5, CANADA \\ 3 Geological Survey of Pakistan- Northern Area, Plot N. 84, H-8/1, Islamabad, PAKISTAN \\ * For correspondence, email: khattori@uottawa.ca
}

Exhumed rocks from subduction zones provide information relevant to element transfer fromslabs to the overlyingmantlewedges. Dehydration reaction of a slab during its subduction results in the hydration of the overlying mantle peridotites, forming a serpentinite layer at the base of the wedge mantle. Eventual breakdown of the serpentinites releases water and contributes to partial melting of the interior of the mantle wedge for arc magmatism (Hattori and Guillot 2003). Fluid-mobile elements behave together with water and are transferred from slabs to the overlying mantle wedge. They are enriched in fore-arc mantle serpentinites and also arc magmas (Hattori and Guillot 2003). Most chalcophile elements (copper like elements) are soluble in aqueous fluids, but they may not be mobile in rocks with high sulphide sulphur because they are fixed in sulphide minerals. To evaluate the behaviour of sulphur and chalcophile elements in continental subduction zones, we examined the occurrence of sulphides in ultrahigh pressure rocks of the Stak and Tso Morari massifs in the western Himalayas. Both massifs represent the subducted margin of the Indian continent after its collision with Asian continent. The Stak rocks have the bulk composition of alkaline mafic igneous rocks and likely related to a hot spot magmatism. Our recent $\mathrm{U} / \mathrm{Pb}$ ages of zircon using a SHRIMP suggest the protolith of $\sim 60.4 \mathrm{Ma}$ and the peak metamorphism ( $23 \mathrm{kbar}, 750^{\circ} \mathrm{C}$ ) at $51 \mathrm{Ma}$ (Riel et al., this volume). These rocks were exhumed to $11 \mathrm{kbar}$ under amphibolite facies condition. For the Tso Morari rocks, they underwent the peak metamorphism of 20-25 kbar and $580 \pm 60^{\circ} \mathrm{C}$ (Guillot et al. 1997) at $\sim 53 \mathrm{Ma}$ (Leech et al. 2005) and exhumed with a similar P-T-t path as the Stak rocks.

Chalcopyrite $(\mathrm{CuFeS} 2)$ and pyrrhotite $(\mathrm{FeS})$ are the two main sulphide minerals in the samples from the Stak massif. They form globular inclusions in garnet and angular grains outside garnet. Inclusions in garnet are predominantly pyrrhotite with minor chalcopyrite. The Tso Morari rocks contain minor pyrrhotite inclusions in garnet, with no chalcopyrite observed in the studied samples. The common occurrence of sulphide inclusions in garnet from both massifs indicates that sulphide sulphur is transferred deep into the mantle as garnet is stable in the upper mantle.

The lack of chalcopyrite in the Tso Morari rocks is explained by its protolith, and/or high oxidation condition during their subduction. The protoliths of the Stak massif are plume-related mafic igneous rocks. Copper contents are generally high in mafic igneous rocks, especially plume-related rocks. On the other hand, the protoliths of the Tso Morari rocks are shallow water sediments from granitic sources on the northern Indian continent. The protoliths of the studied rocks may have had low copper and sulphur contents, although their concentrations vary widely in such sedimentary rocks. It is also probable that both copper and sulphur may have been lost during the subduction of the Tso Morari rocks considering high oxidation state of the subduction zone (Hattori et al. 2005). Evaporite

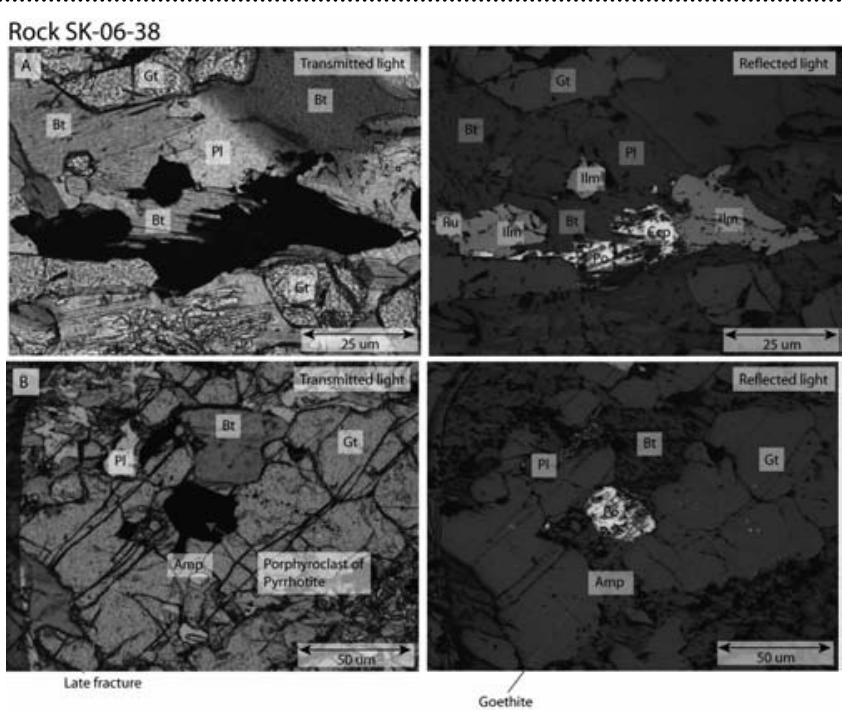

beds of sulphate in the Tso Morari massif (e.g., Gaetani et al. 1986) likely maintained high oxidation state. Sulphide sulphur would have been destabilized to sulphate in the Tso Morari rocks.

During the exhumation of the Stak and Tso Morari massifs, they were retrogressed under amphibolitic facies condition to form amphiboles. Sulphide grains associated with amphiboles are partially hydrated and oxidized to goethite $(\mathrm{FeOOH})$. The evidence suggests that the retrogression is accompanied by the dissolution of sulphur and copper in aqueous fluids and their transfer into the overlying mantle or crust.

\section{References}

Gaetani M, R Casnedi, E Fois, E Garzanti, F Jadoul, A Nicora and A Tintori, 1986. Stratigraphy of the Tethys Himalaya in Zanskar, Ladakh. Riv. Ital. Paleont. Stratigr. 91: 443-478

GuillotS,J de Sigoyer,JMLardeauxand GMascle. 1997.Eclogiticmetasediments from the Tso Morari area (Ladakh, Himalaya) : Evidence for continental subduction during India-Asia convergence. Contribution to Mineralogy and Petrology 128: 197-212

Hattori K and S Guillot. 2003. Volcanic fronts form as a consequence of serpentinite dehydration in the forearc mantle wedge. Geology 21: 525-528

Hattori K, Y Takahashi, S Guillot and B Johanson. 2005. Occurrence of Arsenic (V) in fore-arc mantle serpentinites: X-ray absorption spectroscopy study. Geochim. Cosmochim. Acta 69: 5585-5596

Leech ML, S Singh, AK Jain, SL Klemperer and RM Manickavasagam. 2005. The onset of India-Asia continental collision: Early, steep subduction required by the timing of UHP metamorphism in the western Himalaya. Earth and Planetary Science Letters 234: 83-97

Riel N, K Hattori, S Guillot, N Rayner, B Davis, M Latif and AB Kausar, 2008. SHRIMP zircon ages of eclogites in the Stak massif, northern Pakistan. Himalayan Journal of Sciences 5 (7): 119 